\title{
Socio-demographic characteristics of the mothers and infant feeding practices in some semi urban villages of a selected Upazilla

\author{
Mahejabin $\mathrm{F}^{1}$, Khan $A W^{2}$, Sultana $M^{3}$
}

\begin{abstract}
To identify the socio-demogrsphic factors and to determine the breast-feeding and weaning practices of the mothers of infants in some selected villages of Dhamrai.

A descriptive type of cross sectional study was conducted from July to December, 2011. A total of 320 mothers were interviewed having infant up to the age of 1 year. A validated questionnaire, which consists of questions relating to socio-demographic data, breast-feeding and weaning practices, was used.

The total number of mothers interviewed was 320 who had infants up to 1 year of age. The mothers were mostly 154(48.1\%) aged 21- 25 years and 107 (33.4\%) aged 26-30 years. Most 151 (47.2\%) of the mothers were educated up to primary level and 96(30\%) up to secondary level. 71 mothers were illiterate. The mothers were mostly 190(55.4\%) belonged to nuclear family and 129(40.3\%) joint family. Most 301(94.1\%) of the mothers were housewife. The monthly income of the respondents were Taka 5001-10000 amongst $149(47 \%)$ and Taka $\leq 5000132(41 \%)$. The mean monthly family income of the respondents was $7626.56 \pm 3171.248$ Taka. Out of 320 infants, 137 (43\%) were aged 9-12 months, 124 (39\%) were 6-9 months and 59 (18.4\%) infants were aged $\leq 6$ months. The infants mostly 96(30\%) weighted more than $8 \mathrm{~kg}, 95$ $(30 \%)$ weighted $6-8 \mathrm{~kg}$ and $76(24 \%)$ weighted $4-6 \mathrm{~kg}$. All the mothers had initiated breast feeding to their infants and majority 298(98\%) were on breast feeding and 57 (96.6\%) were on exclusive breast feeding during the study. The infants of $\leq 6$ months fed breast milk 8 times or more in a day, the infants of 6-9 months fed breast milk 6-8 times in a day and those not breast fed they fed liquid/soft foods 4-6 times in a day. The infants of 9-12 months fed breast milk 4-6 times in a day and those not breast fed they fed liquid/soft foods 68 times in a day. The infants mostly 57(96.6\%) were on exclusive breast feeding at the age of $\leq 6$ months and on complementary feeding $77(62 \%)$ and $83(60.5 \%)$ infants at the age of 6-9 and 9-12 months respectively. The infants were not on breast feed $13(10.5 \%)$ at the age of $6-9$ months and $23(16.8 \%)$ at the age of $9-12$ months. Out of 320 respondents 315(98.4\%) were aware about the usefulness of breast feeding and 5(1.6\%) were not aware. Out of 320 respondents $269(84.1 \%)$ were aware about the complementary food and $51(15.9 \%)$ were not aware. Out of 320 respondents $218(68.1 \%)$ were aware about the knowledge of starting weaning food and 102(31.9\%) were not aware about the starting of weaning food.

The results of the study indicate that the breast feeding practices among the mother of urban areas were well practiced.
\end{abstract}

CBMJ-2013; Jan: Vol-02, No-01: P: 43-48 Key words: Breast feeding, Exclusive breast feeding, Weaning, Complementary feeding

\section{Introduction}

Breast milk provides the main source of nourishment in the first year of life. ${ }^{1}$ Breastfeeding has a unique biological and emotional influence on the health of both mother and infant. It is further more an important determinant of infant health in the prevention of malnutrition and infections. ${ }^{2}$ The World health organization (WHO) recommends exclusive breast feeding for the first six months of age with early initiation and continuation of breast feeding for 2 years or more together with introduction of adequate complementary foods starting at six months of age. ${ }^{3}$ Breast milk is the best and safest food for young babies and it maintains optimum growth up to the age 4-6 months and thereafter faltering of growth occurs in most of
1. * Dr. Farzana Mahejabin Assistant professor and Head Department of Community Medicine Dhaka Community Medical College

2. Prof. Dr. Abdul Wadud Khan Principal and Professor of Community Medicine Dhaka Community Medical College

3. Dr. Masuda Sultana Assistant professor, Department of Physiology, Dhaka Community Medical College, Mogbazar, Dhaka.

\author{
* Address of correspondence \\ Email:farzanamahejabin@yahoo.com \\ Mobile: +8801731 186326
}


our children. ${ }^{4}$ At the age of 6 months breast milk, should be supplemented by additional foods rich in protein and nutrients. ${ }^{1}$ It is important that the babies are given extra foods along with breast milk at the age of six months and in sufficient amounts to enable them to grow and stay healthy. ${ }^{4}$ These are usually cow's milk, fruit juice, soft cooked rice, dhal and vegetables. ${ }^{1}$ World-wide about $30 \%$ of children under 5 are stunted as a consequence of poor feeding and repeated infections. $^{5}$ In developing countries, an estimated 50.6 million children aged less than five years are malnourished. Recent data from the World Health Organization showed that $60 \%$ of all deaths, occurring among under-five children in developing countries, could be attributable to malnutrition. ${ }^{6}$ Mothers of poor nutritional status, has a remarkable ability to breast feed her infant for prolonged periods. Breast feeding should be initiated within an hour of birth. The first milk which is called colostrums is the most suitable food for the baby during early period, because it contains a high concentration of protein \& other nutrients the body needs; it is also rich in anti-infective factors which protect the body against respiratory infections \& diarrhoeal diseases. Under any circumstances breast milk is the ideal food for the infants. Artificial feeding is a hazardous procedure in homes because of the danger of the contamination. It is very important to advice the mothers to avoid the feeding bottles. Breast milk is almost completely digested \& utilized for growth. It contains other proteins whose functions are anti-infective. Human milk contains vitamins \& minerals in sufficient amount. Weaning started gradually around the age of 6 month. It should be supplemented by suitable foods rich in protein $\&$ other nutrients. These are called "supplementary food". The weaning period is most crucial period in child development, for during the weaning process children are particularly exposed to the deleterious synergistic interaction of malnutrition \& infection. Weaning If not done properly is often followed by malnutrition and infection. Knowledge of weaning foods \& practices is an important aspect of child health \& development. At the age of 1 year the child should receive solid foods consisting of cereals, pulses, vegetables \& fruits. Efforts should be therefore be made to design \& promote the use of feeding practice of infants. A child who is breast-fed has greater chances of survival than a child artificially feed. ${ }^{1}$ With these backgrounds the present study was under taken to find out the socio-demographic status of the mothers and their Infant feeding practices in some selected rural areas of Bangladesh.

\section{Methods:}

This was a descriptive cross-sectional study conducted to find out the socio-demographic factors, breast feeding and weaning practices and awareness regarding usefulness of breast feeding and weaning in four selected semi urban villages at Dhamrai Upazilla health complex Dhaka.

The sample was selected from Srirampur, Dautia, Kalampur and Sutipara of Dhamrai upazilla, the subjects were the breast fed mothers having infants up to 1 year of age. All the infants within 1 year of age were included in the study. Trained interviewers collected information on age, sex, socio-economic characteristics and feeding practices of the infant by interviewing mothers.

A pretested questionnaire was used to collect data. A questionnaire was designed relating to demographic data (mother's age, infant's age, monthly income, the mother's educational level and breast feeding and weaning practices). A questionnaire survey was conducted by the interviewer using the local language and accuracy of response.

All data were collected at the women's homes by trained interviewers and paramedics. Structured questionnaires and open ended questions were used for data collection. All questionnaires were pretested and raised accordingly. The questionnaires were first prepared in English and then translated into Bangla. Informed consent was obtained from the women about their participation in the study.

Mothers were asked to recall about general feeding patterns in the previous month, that is, whether the baby was still breast fed and the feeding of plain water; water containing sugar, glucose, or jaggery; fruit juice, cow's milk, semisolid and solid foods and number of times the baby was breast fed during the day. 
Original Article

\section{Results:}

The total numbers of mothers in the study were 320 who had infants up to aged of 1 year.

The mothers were mostly 154 (48.1\%) aged 21-25 years and 107 (33.4\%) aged 26-30 years. The mean age of the respondent is 25.34 years and SD $=( \pm)$ 4.281. The mothers were mostly $190(55.4 \%)$ belonged to nuclear family and $129(40.3 \%)$ joint family. Most $151(47.2 \%)$ of the mothers were educated up to primary level and 96 (30\%) up to secondary level. Illiterate mothers were 71(22.2\%). The mothers 301(94.1\%) were mainly housewife. The monthly income of the respondents were Taka 5001- 10000 amongst 149(47\%)- with mean income with SD was Taka 7626.56 and +3171.248 and Taka $\leq 5000$ among 132(41\%). [Table-1] The age of the infants were evenly distributed in all age groups. Out of 320 infants, 137 (43\%) were aged 9-12 months, 124 (39\%) were 6-9 months and $59(18.4 \%)$ infants were aged $\leq 6$ months. [Table-2] The infants of $\leq 6$ months fed breast milk 8 times or more in a day, the infants of 6-9 months fed breast milk 6-8 times in a day and those not breast fed they fed liquid/soft foods 4-6 times in a day. The infants of 9-12 months fed breast milk 4-6 times in a day and those not breast fed they fed liquid/soft foods 6-8 times in a day. [Table: 3] Out of 320 infants, majority $284(88.8 \%)$ infants were on breast feeding. The infants mostly $57(96.6 \%)$ were on exclusive breast feeding at the age of $<6$ months and on complementary feeding 77 (62\%) and $83(60.5 \%)$ infants at the age of $6-9$ and $9-12$ months respectively. The infants were not on breast feed $13(10.5 \%)$ at the age of $6-9$ months and $23(16.8 \%)$ at the age of $9-12$ months. [Table -4] Out of 320 respondents $315(98.4 \%)$ were aware about the usefulness of breast feeding and $5(1.6 \%)$ were not aware. 269(84.1\%) were aware about the complementary food and 51(15.9\%) were not aware. 218(68.1\%) were aware about the knowledge of starting weaning food and 102(31.9\%) were not aware about the starting of weaning food. [ Table-5]
Table: 1 Distribution of the respondents according to socio-demographic characteristics [ $n=320]$

\begin{tabular}{lccc}
\hline $\begin{array}{l}\text { Socio- } \\
\text { demographic } \\
\text { characteristics }\end{array}$ & Frequency Percent & Mean \pm SD \\
\hline Age(Years) & & & \\
$\leq 20$ years & 33 & 10.3 & 4.281 \\
$21-25$ years & 154 & 48.1 & \\
$26-30$ years & 107 & 33.4 & \\
$\geq 30$ years & 26 & 8.1 &
\end{tabular}

\section{Type of Family}

$\begin{array}{lcc}\text { Nuclear } & 190 & 59.4 \\ \text { Joint Family } & 129 & 40.3 \\ \text { Extended Family } & 1 & 0.3\end{array}$

\section{Educational}

Qualification

$\begin{array}{lcc}\text { Illiterate } & 71 & 22.2 \\ \text { Primary level } & 151 & 47.2 \\ \text { Secondary level } & 96 & 30.0 \\ \text { Higher } & 2 & 6\end{array}$

Secondary and

above

\section{Occupation}

House wife

301

94.1

Agriculture

5

1.6

Service Holder

Family Income

$7262.56 \pm$

$\leq 5000 \mathrm{TK}$

5001-10000 TK 149

46.6

$>10000 \mathrm{TK}$

39

12.2 
Table 2: Frequency distribution.

\begin{tabular}{llll}
\hline Age of child & Frequency & Percent & Weight \\
\hline$\leq 6$ months & 59 & 18.4 & $2.9 \mathrm{~kg}$ \\
6-9 months & 124 & 38.8 & $7.3 \mathrm{~kg}$ \\
9-12 months & 137 & 42.8 & $8.1 \mathrm{~kg}$ \\
\hline Total & 320 & 100.0 &
\end{tabular}

Mean $=8.44 ;(S D= \pm 3.042)$

Table: 3 Age specific feeding

\begin{tabular}{|c|c|c|c|c|}
\hline Age-group (months) & Breastfed & Type of food & Frequency and amount & $\begin{array}{l}\text { Reasons for not breast } \\
\text { feeding }\end{array}$ \\
\hline $\begin{array}{l}\leq 6 \text { months } \\
6-9 \text { months }\end{array}$ & $\begin{array}{l}\text { Yes } \\
\text { Yes } \\
\text { No } \\
\text { Yes } \\
\text { No }\end{array}$ & $\begin{array}{l}\text { Only breast milk } \\
\text { Breast milk } \\
\text { liquid/Soft food } \\
\text { Breast milk } \\
\text { Liquid/Soft food }\end{array}$ & $\begin{array}{c}8 \text { times or more } \\
6-8 \text { times } \\
\text { 4-6 times } \\
\text { 4-6 times } \\
6-8 \text { times }\end{array}$ & $\begin{array}{l}\text {-Insufficient breast milk. } \\
\text {-Work load. } \\
\text {-Illness of mothers. } \\
\text { - Lack of knowledge. }\end{array}$ \\
\hline
\end{tabular}

Table: 4 Feeding status of infants by age $\mathrm{n}=320$

\begin{tabular}{|c|c|c|c|c|c|c|}
\hline \multirow[t]{2}{*}{$\begin{array}{c}\text { Age } \\
\text { (months) }\end{array}$} & \multirow[t]{2}{*}{$\begin{array}{l}\text { Not breast feed } \\
\text { (Other food) }\end{array}$} & \multirow[t]{2}{*}{$\begin{array}{l}\text { Exclusive } \\
\text { breast feed }\end{array}$} & $\begin{array}{l}\text { Breast feeding } \\
\text { and other foods }\end{array}$ & Total & & \\
\hline & & & Plain water & Cow's milk & $\begin{array}{l}\text { Complementary } \\
\text { feeding }\end{array}$ & \\
\hline$\leq 6$ months & 0 & $57(96.6 \%)$ & 0 & $02(3.38 \%)$ & 00 & 59(18.4\%) \\
\hline 6-9 months & $13(10.5 \%)$ & 00 & $03(2.4 \%)$ & $31(25 \%)$ & $77(62 \%)$ & $124(38.7 \%)$ \\
\hline $\begin{array}{c}9-12 \\
\text { months }\end{array}$ & $23(16.8 \%)$ & 00 & 00 & $31(22.6 \%)$ & $83(60.5 \%)$ & $137(42.8 \%)$ \\
\hline Total & $36(11.2 \%)$ & $57(17.8 \%)$ & $03(0.9 \%)$ & $64(20 \%)$ & $160(50 \%)$ & $320(100 \%)$ \\
\hline
\end{tabular}

Table: 5 Distribution of the respondents by Knowledge of usefulness of breast feeding, complementary feeding and starting weaning food

\begin{tabular}{|l|c|c|}
\hline $\begin{array}{l}\text { Knowledge of usefullness of } \\
\text { breast feeding }\end{array}$ & Number & Percent \\
\hline Yes & 315 & 98.4 \\
\hline No & 5 & 1.6 \\
\hline & & \\
\hline $\begin{array}{l}\text { Knowledge on } \\
\text { Complementary food }\end{array}$ & 269 & 84 \\
\hline Yes & 51 & 16 \\
\hline No & & \\
\hline & & \\
\hline $\begin{array}{l}\text { Knowledge of starting } \\
\text { weaning food }\end{array}$ & 218 & 68 \\
\hline Yes & 102 & 32 \\
\hline No & & \\
\hline
\end{tabular}

\section{Discussion:}

The findings of the study suggested that the majority $(98 \%)$ of the mothers were breast feeding at the time of interview. Similar findings were found in the study done in the Vhemble Distric of Limpopo Province ${ }^{2}$ and other countries where $90 \%$ of mothers in urban areas breast feed their babies. The reasons given by the mothers who were not breast feeding $(2 \%)$ in the study were not enough breast milk, work load, or health reasons. Almost similar findings were observed where insufficient breast milk, work 
load, mother's illness and lack of knowledge or awareness was the reason.

Exclusive breast feeding practices under six months was found $96.6 \%$ by the present study. But in a study on 'Infant and young child feeding Practices in Bunkura District, West Bengal India' showed that exclusive breast feeding under six months was $57.1 \%^{3}$. It may be due to the lack of awareness about the usefulness of breast milk among the mothers and could be attributed to supplementation with plain water in early months and milk other than breast milk in later months. Another study on "Appropriate infant feeding practices result in better growth of infants and young children in rural Bangladesh" showed that about 92\% of mothers gave colostrums to their infants, and only $8 \%$ of them give prelacteal food or drink. Almost all infants (99.4\%) were breast fed at 1 month of age and $92 \%$ of them were still breast feeding at 12 month of age. The proportion of infants who were exclusively breast fed decreased from $78.3 \%$ at 1 month of age to $10.7 \%$ at 6 months of age.

The study done in the Vhemble Distric of Limpopo Province ( South Africa) found that only $7.6 \%$ of the mothers had practiced exclusive breast feeding for infants aged below $t$ three to six months. Similar findings are observed in the same country, which report that only $10.4 \%$ and $6.7 \%$ of the infants under six months had been exclusively- breast fed. It is clear from the observations that very few mothers (approximately10\%) in the country were practiced exclusive breast-feeding. ${ }^{2}$ These may due to the fact that the mothers were not aware of the importance of breast feeding.

Haque $\mathrm{M} \mathrm{J}$, et al. conducted a study on "Infant Feeding Practice by the Rural Mothers of Dinajpur District" ${ }^{8}$ and found that the common weaning food were Suji $(43.5 \%)$, Khichuri (36.1\%), boiled eggs (25.6\%) and fruit juice $(24.4 \%)$ which was more or less similar to this study where Khichuri/ Hotchpotch was taken 92(49.7\%), Suji $47(21.5 \%)$ and mixed food 57 (30.7\%), as weaning food. The present study showed that at 6-9 months of age $62 \%$ infants were fed with complementary foods and at 9-12 months of age $60.5 \%$ infants were fed with complementary foods. The study on "Appropriate infant feeding practices result in better growth of infants and young children in rural Bangladesh" observed that at 6 months of age $49.6 \%$ of the infants were given semisolid foods and $66.4 \%$ at 9 months of age. At 6 months of age $66.7 \%$ of infants were fed with complementary foods that increased to $95 \%$ at 9 months of age. ${ }^{7}$

The present study also showed that most of the mothers 315(98.4\%) were aware about the usefulness of breast feeding. These findings are almost similar with findings conducted by Li M Wen, et al. in the study on "Intention of breast feeding and awareness of health recommendations: findings from firsttime mothers in southwest Sydney, Australia". ${ }^{9}$ They found breast feeding decisions and practices are influenced by multiple factors including knowledge, attitudes and beliefs as well as socio-cultural and physiological factors. ${ }^{10-14}$ In developed countries like Australia, mothers who are younger (under 25 years old), have less education, or are most socio-economically disadvantage tend to have lower rates of full breast feeding, rates of initiation and duration of breast feeding. ${ }^{15,16}$

A descriptive cross sectional study on mother's knowledge and practice related to weaning at Butajira, S.Ethiopia in 1994 and revealed that $68 \%$ children were on weaning diet. $^{17}$ This findings was similar to this findings where we found 218 (68.1\%) had the knowledge of starting weaning food.

\section{Conclusion:}

In conclusion, the findings of this study indicate that almost all mothers practiced breast-feeding and did so exclusively. Most of the mothers had introduced solid foods to their child by six months and khichuri being the main weaning food. This has implications on efforts by health authorities to encourage exclusive breast feeding and introduction of weaning food at six months and continuation of breast milk up to 2 years. The benefits of exclusive breast feeding have been well demonstrated; these include satisfactory feeding practices, mother's attitude and knowledge on breastfeeding. Further follow up is needed to improve the sustainability of exclusive breast feeding and to establish the support structures and systems that women to be able to breast feed exclusively for the recommended period. 


\section{References:}

1. K.Park. Preventive and Social Medicine. $21^{\text {ist }}$ ed. 2011.

2. Infant-feeding practices of mothers and the nutritional status of infants in the Vhemble District of Limpopo Province

3. Sinhababu A, Mukhopadhay D K,Panja T K et al. Infant and young child feeding practices in Bankura District, West Bengal, India; J Health Popol Nutr. 2010 June; 28(3): 294-299.

4. Das D.K, Talukder M. Q-K, Sella G.E,Infant feeding Practices in Rural Bangladesh; INDIAN JOURNAL OF PEADIATRICS 1992;59: 573-577.

5. WHO/Global strategy for infant and Young Child Feeding www.who.int/nutrition/topics/global_strategy/e n/index.html

6. Faruque A.G.S., Ahmed A.M, Ahmed T et al. Nutrition: Basis for Healthy Children and Mothers in Bangladesh. J Health Popul Nutr. 2008 September; 26(3): 325-339.

7. Saha K.K., Frongillo E.A., Alam D.S., Arifeen S.E., et al: Appropriate infant feeding practices result in better growth of infants and young children in rural Bangladesh, AmJ Clin Nutr june 2008 Vol. 87 No.6 1852-1859.

8. Haque $M J$ J, Rahman M M, Sarkar SK, Ali MA, et al: Infant Feeding Practice by the Rural Mothers of Dinajpur Diatrict, Journal/DjMCJ V3/14_djmcj_v3_il_Jawad_Infant.pd.

9. Li M Wen, Louise A Baur, Chris Rissel, et al. Intension of breastfeed and awarness of health recommendations: findings from firsttime mothers in southwest Sydney, Australia: International Breastfeeding Journal 2009, 4:9

10. Garden $F$, Hector $D$, Eyeson-Annan $M$, Webb $K$ : Breast feeding in New South Wales: Population Health survey 2003-2004. Sydney; NSW Centre for public Health Nutrition, University of Sydney, Australia: International Breastfeeding Journal 2009, 4:9
11. Chambers JA, Mclnnes RJ, Hoddinott $P$, Alder EM: A systematic review of measures assessing mothers' knowledge, attitudes, confidence and satisfaction towards breastfeeding.

12. Papinczak TA, Turner CT: An analysis of personal and social factors influencing initiation and duration of breastfeeding in a large Queensland maternity hospital. Breastfeeding Review 2000,8 (1): 25-33.

13. Kong SKF, Lee DTE: Factors influencing decision to breastfeed. Journal of Advanced Nursing 2004, 46:369-379.

14. Chezem J, Friesen C, Boettcher J: Breastfeeding knowledge, breastfeeding confidence, and infant feeding plans: effects on actual feeding practices.

15. Hector $D$, Webb K,Lyner S: Describing breastfeeding practices in New South Wales using data from the NSW Child Health Survey, 2001. New South Wales Public health buttetin 2005,16(3-4):47-51.

16. Journal of Obstetric, Gynecology, \& Neonatal Nursing 2003,40-47. Feeding:Status and Its determinants in a Rural Bangladesh. International Medical Journal March 2004; 11(1): 19-23.

17. Bekele A, Berhane Y: Weaning in Butajira, south Ethiopia: a study on mother's knowledge and practice: Ethiopia Med J. 1998 Jan; 36(1):37-45. 